\title{
Fermentative and Bromatological Characteristics of Piata Palisadegrass Ensiled with Energetic Brans
}

\author{
Rozana Castro Perim1, Kátia Aparecida de Pinho Costa1, Patrícia Soares Epifanio1, \\ Wender Ferreira de Souza ${ }^{2}$, Ricardo Francischini ${ }^{3}$, Daniel Augusto Alves Teixeira1, \\ Walkíria Guimarães Carvalho ${ }^{1}$, Divino Rosa dos Santos Jr. ${ }^{1}$ \\ ${ }^{1}$ Goiano Federal Institute, Rio Verde, Brazil \\ ${ }^{2}$ Federal University of Bahia, Salvador, Brazil \\ ${ }^{3}$ University of Rio Verde, Rio Verde, Brazil \\ Email: katiazoo@hotmail.com
}

Received 28 December 2013; revised 5 February 2014; accepted 2 March 2014

Copyright (C) 2014 by authors and Scientific Research Publishing Inc.

This work is licensed under the Creative Commons Attribution International License (CC BY). http://creativecommons.org/licenses/by/4.0/

(c) (i) Open Access

\section{Abstract}

The objectives of this study were to evaluate the fermentative and bromatological characteristics of Piata palisadegrass that was ensiled with energetic brans and to assess the costs of different additive levels. This experiment was conducted at the Goiano Federal Institute on the Rio Verde campus in Goiás State, Brazil. The experimental design was entirely random with four replications in a $4 \times 5$ factorial scheme that included four energetic brans (millet, maize, sorghum and wheat) and five levels $(0 \%, 8 \%, 16 \%, 24 \%$ and $32 \%)$. The energetic brans can be considered as a good source of additives for Piata palisadegrass ensiling, which improves the qualitative and nutritional fermentative characteristics of the silage. The maize and wheat brans were the most efficient for improving the fermentative characteristics of the silage. However, millet bran was the most efficient for improving the bromatological characteristics. In addition, the wheat bran had the greatest influence on the final production cost and the sorghum and millet brans were the most economically feasible. Overall, the addition of $24 \%$ bran is recommended due to its beneficial impact on silage quality and the average final production cost of the silage.

\section{Keywords}

Organic Acids; Brachiaria brizantha; Ensiling; Nutritive Value 


\section{Introduction}

The midwestern region of Brazil is characterized by two defined seasons each year: a rainy period and a dry period. These periods result in seasonal forage production. High forage production occurs during the rainy season when rain is abundant. In contrast, production is limited during the dry season. Thus, the distribution of forage production throughout the year is not uniform [1]. Consequently, Brazilian livestock have evolved. Thus, new techniques that offer balanced diets for Brazilian livestock are of interest to farmers for improving bovine productivity. Among these new techniques, ensiling is highlighted. The use of silage from forage grasses as bovine feed has increased due to the high potential of grass production. To obtain silage with good nutritional value from tropical grasses, the grasses must be collected at young ages based on their growth cycle. However, during this stage of development, the forage generally has a low dry mass (DM) concentration, which is associated with the low soluble carbohydrate concentrations in tropical grasses. This low dry mass concentration may inhibit the fermentation process and compromise the final quality of the silage [2]. Thus, additives should be added to grass silage to enhance the silage quality. Among the various additive alternatives, energetic brans, such as maize, sorghum, millet and wheat, are emphasized. Due to their nutritional value, these brans can be used as energetic additives for silage. These brans serve as a source of energy, protein and soluble carbohydrates, prevent secondary fermentation, and increase the nutritional value of the silage. In addition, these brans provide an alternative for improving silage quality by compensating for the low DM concentrations and by contributing to silage fermentation [3]. The use of these brans in Piata palisadegrass silage is feasible because the Midwestern region of Brazil is one of the largest producers of these grains. This grain production facilitates access to the grains and allows for more flexible pricing. Thus, the objectives of this study were to evaluate the fermentative and bromatological characteristics of Piata palisadegrass ensiled with energetic brans and to determine the costs of the different additive levels.

\section{Material and Methods}

The experiment was conducted at the Goiano Federal Institute (Goiás State, Brazil) on the Rio Verde Campus. The Piata palisadegrass was established for silage production in January 2012 over an area of approximately 180 $\mathrm{m}^{2}$. The staging area was conducted with a standardized harvest in November 2012, and then held maintenance fertilization with $120 \mathrm{~kg} \cdot$ nitrogen $\cdot \mathrm{ha}^{-1}$ and $60 \mathrm{~kg}$ of $\mathrm{K}_{2} \mathrm{O} \cdot \mathrm{ha}^{-1}$ in coverage, using ammonium sulfate and potassium chloride as nutrient sources. An entirely random experimental design was used with four repetitions and a $4 \times 5$ factorial scheme that included four energetic brans (millet, maize, sorghum and wheat) and five percentage levels $(0 \%, 8 \%, 16 \%, 24 \%$ and $32 \%)$. The brans were obtained by grinding the grains and passing them through a $2 \mathrm{~mm}$ sieve. The addition levels were determined based on the natural Piata palisadegrass material. For the ensilaging, the Piata palisadegrass was harvested at 45 days after maintenance fertilization, at $20 \mathrm{~cm}$ from ground level, using backpack crush cutter. Afterwards, the forage was minced into 10 - 30 mm-particles, with a stationary shredder, and ground. Then, the material was homogenized with the meals, according to the different levels determined, and stored in PVC experimental silo, with $10 \mathrm{~cm}$ diameter and $40 \mathrm{~cm}$ length. The specific mass of silo was of $1.12 \mathrm{~kg} \cdot \mathrm{dm}^{3}$. The silage was compacted with iron pendulum and the silos were sealed with PVC caps and adhesive tape to preclude the entry of air. Immediately after, they were stored at room temperature and protected from rain and sunlight. The silos were opened after 60 days of fermentation, and the silage from the upper and lower portions of each silo was discarded. The central portion of the silo was homogenized and placed in plastic trays. After opening the silos, part of the in natura silage was separated and analyzed for $\mathrm{pH}$, titratable acidity, and buffering capacity based on the methods of [4]. After this procedure, the silage sample was removed and divided into two parts. The first part was packed into plastic sacks and frozen. To determine the $\mathrm{N}-\mathrm{NH}_{3} / \mathrm{NT}$ (ammoniacal nitrogen), soluble carbohydrate (CHOsol) and organic acid concentrations, the samples were thawed before extracting their liquid. The acetic, propionic, lactic and butyric acid concentrations were determined with gas chromatography based on the methods of [5]. The other part of about $1 \mathrm{~kg}$ was weighed and taken to a forced air oven at $55^{\circ} \mathrm{C}$ for 72 hours to determine the pre-drying matter. Later, the samples were ground in a Willey type mill, with $1 \mathrm{~mm}$-sieve, to be analyzed. The bromatological composition of the silage was determined by measuring the dry matter (DM), crude protein (CP), neutral detergent fiber (NDF), acid detergent fiber (ADF), lignin, cellulose, hemicellulose, ether extract (EE) and mineral material (MM) concentrations based on the methods of [4]. The total digestible nutrient (TDN) content was obtained using the equation 
proposed by [6]. For the in vitro digestibility of dry matter (IVDMD), the technique described by [7] was adopted. This technique was adapted to the artificial rumen that was developed by ANKON® by using the "Daisy incubator" instrument from Ankom Technology. The ruminal liquid was collected from two fistulated male bovines with an average weight of $550 \mathrm{~kg}$. These animals were allowed to graze on Brachiaria brizantha cv. Marandu. Before the ensiling, the Piata palisadegrass and the meals were submitted to bromatological analysis (Table 1), according to the methods described above.

Regarding the economic analysis, the additional cost of using different bran levels (AdC) and the final silage cost $\left(\mathrm{R} \$ \cdot \operatorname{ton}^{-1}\right)$ were calculated. Next, the additional average cost (AvC) was calculated for the additives as follows, based on the ratio of the the additional cost of using different bran levels to the final silage quantity (in $\mathrm{R} \$ \cdot \mathrm{ton}^{-1}$ ), by the equation:

$$
\operatorname{AvC}=\frac{\mathrm{CAd}}{\mathrm{Y}}
$$

Wherein:

AvC $=$ Additional average cost

CAd = Additional cost of using different bran levels

$\mathrm{Y}=$ Final silage quantity

After determining the average costs for using the additives, the marginal costs were calculated. The marginal cost was defined as the ratio between the average cost variation when the amount of bran in the silage increased and the ensiled quantity varied.

$$
\mathrm{CMg}=\frac{\Delta \mathrm{CT}}{\Delta \mathrm{Y}}
$$

Wherein:

$$
\mathrm{CMg}=\text { Marginal costs }
$$

$\Delta \mathrm{CT}=$ Cost variation

$\Delta \mathrm{Y}=$ Ensiled quantity varied

The bran prices were based on historic quotes from the Rio Verde-Goiás market in Brazil.

The data were subjected to an analysis of variance test that considered the addition levels of the additives and the interactions between these factors as sources of variation. These averages were compared by using the Tukey test with a probability of 5\% in the SISVAR 4.6 statistical software [8]. The additive levels were evaluated by regression analysis, from which the coefficient of determination was evaluated. The regression equations were generated from the graphs in Sigma Plot.

Table 1. Chemical composition of the Piata palisadegrass, brans and millet, maize, sorghum and wheat, used to produce the silage.

\begin{tabular}{cccccc}
\hline Chemical composition & Piata palisadegrass & Bran millet & Bran maize & Bran Sorghum & Bran wheat \\
\hline DM (\%) & 19.20 & 89.50 & 88.90 & 88.80 & 88.00 \\
CP (\%) & 13.70 & 16.18 & 9.70 & 10.50 & 17.12 \\
NDF (\%) & 66.50 & 19.03 & 11.59 & 14.15 & 38.81 \\
ADF (\%) & 38.90 & 9.53 & 7.80 & 8.56 & 13.50 \\
Lig. & 4.35 & 2.80 & 1.85 & 2.30 & 3.80 \\
Cell. & 34.55 & 6.73 & 5.95 & 6.26 & 9.70 \\
Hemic. & 27.60 & 9.50 & 3.79 & 5.59 & 25.31 \\
EE (\%) & 2.50 & 4.39 & 4.81 & 4.43 & 3.95 \\
MM (\%) & 6.30 & 3.49 & 3.45 & 3.23 & 4.26 \\
TDN (\%) & 59.40 & 81.03 & 81.67 & 80.52 & 74.53 \\
IVDMD (\%) & 68.30 & 86.50 & 87.50 & 82.40 & 80.65 \\
CHOsol (\%) & 2.43 & 9.75 & 11.50 & 10.30 & 7.30 \\
\hline
\end{tabular}

$\mathrm{DM}=$ Dry matter; $\mathrm{CP}=$ Crude protein; NDF = Neutral detergent fiber; ADF = Acid detergent fiber; LIG. = Lignin; CELL. $=$ Cellulose; HEMIC. = Hemicellulose; EE = Ether extract; $\mathrm{MM}$ = Mineral material; TDN = Total digestible nutrient; IVDMD = In vitro digestibility of dry matter; CHOsol = Soluble carbohydrate. 


\section{Results and Discussion}

The $\mathrm{pH}$, titratable acidity, $\mathrm{N}-\mathrm{NH}_{3} / \mathrm{NT}$, buffering capacity, soluble carbohydrate, organic acid, DM, CP, EE, MM, NDF, ADF, lignin, cellulose, TDN and IVTD values were affected $(\mathrm{P}<0.05)$ by the additives, the levels of addition and by the interactions of these factors.

The addition of the millet and sorghum brans promoted a linear reduction. In addition, the maize and wheat brans promoted a quadratic reduction (Table 2). The minimum points in the linear and quadratic relationships occurred at the $26.26 \%$ and $26.54 \%$ levels, respectively. Silage $\mathrm{pH}$ was not considered to be a good criterion for evaluating fermentation because its inhibitory effect on the bacteria depends on the velocity of the humidity reduction in the medium [9]. Silage that has been properly fermented will have a much lower $\mathrm{pH}$ (be more acidic) than the original forage [10]. However, at the $24 \%$ bran addition level for all brans, the additives efficiently lowered the $\mathrm{pH}$ to values that were near the recommended levels of between 3.8 and 4.2 [11]. These results demonstrate the efficacy of the energetic brans for decreasing the silage $\mathrm{pH}$ because they contain high DM and soluble carbohydrate concentrations relative to the Piata palisadegrass (19.2\%). Thus, adequate fermentation promoted the most rapid $\mathrm{pH}$ decline in the silage and restricted the proteolytic enzymes of the plants, enterobacteria and clostridia, which ensured better quality silage [12]. There addition of bran at $32 \%$ is not necessary. A bran addition of $16 \%$ was sufficient for decreasing the $\mathrm{pH}$, and the best results occurred when a bran addition of $24 \%$ was used. However, the $\mathrm{pH}$ remained above 5.0 in the silage without additives, which indicated that a large production of weaker acids, such as acetic and butyric acids (Table 3), resulted from undesirable fermentation

Table 2. $\mathrm{pH}$, titratable acidity, $\mathrm{N}-\mathrm{NH}_{3}$, buffering capacity and soluble carbohydrate values of the silage from the Piata palisadegrass ensiled with energetic brans.

\begin{tabular}{|c|c|c|c|c|c|c|c|}
\hline \multirow{2}{*}{ Additives } & \multicolumn{5}{|c|}{ Additive Levels (\%) } & \multirow{2}{*}{ Equation } & \multirow{2}{*}{$\mathrm{R}^{2}$} \\
\hline & 0 & 8 & 16 & 24 & 32 & & \\
\hline \multicolumn{8}{|c|}{$\mathrm{pH}$ values } \\
\hline Millet & $5.60 \mathrm{a}$ & $5.00 \mathrm{a}$ & $4.27 \mathrm{ab}$ & $4.15 \mathrm{a}$ & $3.75 b$ & $\mathrm{Y}=5.4640-0.0569 \mathrm{x}^{*}$ & 0.94 \\
\hline Maize & $5.46 a$ & 4.30b & 4.12ab & $3.87 \mathrm{~b}$ & $3.77 b$ & $Y=5.3589-0.1208 x+0.0023 x^{2^{*}}$ & 0.95 \\
\hline Sorghum & $5.47 a$ & $5.02 \mathrm{a}$ & $4.37 b$ & $4.07 a$ & $4.00 \mathrm{a}$ & $\mathrm{Y}=5.3640-0.0486 \mathrm{x}^{*}$ & 0.93 \\
\hline Wheat & $5.48 \mathrm{a}$ & $4.27 \mathrm{~b}$ & $4.00 \mathrm{a}$ & $3.85 b$ & $3.65 b$ & $Y=5.3717-0.1274 x+0.0024 x^{2^{*}}$ & 0.95 \\
\hline CV (\%) & & & 3.96 & & & & \\
\hline \multicolumn{8}{|c|}{ Titratable acidity } \\
\hline Millet & $2.77 \mathrm{a}$ & $4.17 \mathrm{~b}$ & 8.62c & $9.42 b$ & $12.15 b$ & $Y=2.6240+0.3001 x^{*}$ & 0.96 \\
\hline Maize & $3.35 a$ & $9.50 \mathrm{a}$ & $10.7 \mathrm{ab}$ & $12.87 \mathrm{~b}$ & $16.32 \mathrm{a}$ & $Y=4.6860+0.3664 x^{*}$ & 0.93 \\
\hline Sorghum & $3.42 a$ & $4.30 \mathrm{~b}$ & $9.50 \mathrm{ab}$ & $11.57 \mathrm{~b}$ & 14.10ab & $Y=2.8520+0.3579 x^{*}$ & 0.96 \\
\hline Wheat & $3.37 a$ & $8.80 \mathrm{a}$ & $12.20 \mathrm{a}$ & $16.02 \mathrm{a}$ & $16.10 \mathrm{a}$ & $Y=4.7620+0.4083 x^{*}$ & 0.92 \\
\hline CV (\%) & & & 11.60 & & & & \\
\hline \multicolumn{8}{|c|}{$\mathrm{N}-\mathrm{NH}_{3}$ concentration (\% total $\mathrm{N}$ ) } \\
\hline Millet & $4.20 \mathrm{a}$ & $3.75 a$ & 3.30a & $2.72 \mathrm{a}$ & $2.65 a$ & $\mathrm{Y}=4.1500-0.0516 \mathrm{x}^{*}$ & 0.96 \\
\hline Maize & $4.40 \mathrm{a}$ & $3.40 \mathrm{a}$ & $2.47 \mathrm{~b}$ & $2.43 a$ & $2.02 \mathrm{a}$ & $Y=4.0420-0.0696 x^{*}$ & 0.90 \\
\hline Sorghum & 4.53a & $4.15 a$ & $2.90 \mathrm{ab}$ & $2.62 \mathrm{a}$ & $2.55 a$ & $Y=4.4720-0.0691 x^{*}$ & 0.89 \\
\hline Wheat & $4.32 \mathrm{a}$ & 3.92a & $3.42 \mathrm{a}$ & $2.87 a$ & $2.60 \mathrm{a}$ & $Y=4.3720-0.0581 x^{*}$ & 0.99 \\
\hline CV (\%) & & & 12.11 & & & & \\
\hline \multicolumn{8}{|c|}{ Buffering capacity (Emg/100 g de MS) } \\
\hline Millet & 26.38a & 19.49a & $16.57 \mathrm{a}$ & $15.58 \mathrm{a}$ & $12.24 a$ & $\mathrm{Y}=24.4900-0.4024 \mathrm{x}^{*}$ & 0.91 \\
\hline Maize & $27.63 a$ & 18.09ab & 15.33a & 13.49a & $11.68 \mathrm{~b}$ & $Y=26.8840-1.0412 x+0.0183 x^{2 *}$ & 0.96 \\
\hline Sorghum & $26.66 \mathrm{a}$ & 18.89ab & $16.30 \mathrm{a}$ & $13.17 \mathrm{a}$ & $11.03 \mathrm{~b}$ & $\mathrm{Y}=24.6060-0.4623 \mathrm{x}^{*}$ & 0.92 \\
\hline Wheat & 25.09a & $16.99 b$ & $16.52 \mathrm{a}$ & $15.49 \mathrm{a}$ & $12.41 \mathrm{a}$ & $Y=24.0263-0.6743 x+0.0106 x^{2 *}$ & 0.88 \\
\hline CV (\%) & & & 9.48 & & & & \\
\hline \multicolumn{8}{|c|}{ Soluble carbohydrate (\%) } \\
\hline Millet & $2.75 a$ & $3.50 \mathrm{a}$ & $4.50 \mathrm{~b}$ & $6.00 \mathrm{~b}$ & $8.30 \mathrm{~b}$ & $Y=2.8043+0.0414 x+0.0040 x^{2 *}$ & 0.99 \\
\hline Maize & $2.50 \mathrm{a}$ & $4.00 \mathrm{a}$ & $6.25 a$ & $7.75 a$ & $11.00 \mathrm{a}$ & $Y=2.5429+0.1612 x+0.0031 x^{2^{*}}$ & 0.99 \\
\hline Sorghum & $2.00 \mathrm{a}$ & $3.75 a$ & $5.50 \mathrm{a}$ & $7.25 \mathrm{a}$ & $10.25 a$ & $Y=2.1071+0.1607 x+0.0028 x^{2^{*}}$ & 0.99 \\
\hline Wheat & $2.25 \mathrm{a}$ & $3.50 \mathrm{a}$ & $5.00 \mathrm{ab}$ & $6.00 \mathrm{~b}$ & $8.50 b$ & $Y=2.3357+0.1161 x+0.0022 x^{2^{*}}$ & 0.99 \\
\hline CV (\%) & & & 14.53 & & & & \\
\hline
\end{tabular}

Means followed by different lowercases in the column (additive) are significantly different by Tukey's test $(\mathrm{P}<0.05) .{ }^{*}$ significant at $5 \%$ level $\mathrm{N}^{\mathrm{N}} \mathrm{NH}_{3}$ = Ammoniacal nitrogen. 
Table 3. Organic acid concentrations in the Piata palisadegrass silage ensiled with energetic brans.

\begin{tabular}{|c|c|c|c|c|c|c|c|}
\hline \multirow{2}{*}{ Additives } & \multicolumn{5}{|c|}{ Additive Levels (\%) } & \multirow{2}{*}{ Equation } & \multirow{2}{*}{$\mathrm{R}^{2}$} \\
\hline & 0 & 8 & 16 & 24 & 32 & & \\
\hline \multicolumn{8}{|c|}{ Lactic acid (\%) } \\
\hline Millet & $1.89 a$ & 2.60a & $4.51 \mathrm{~b}$ & $7.13 \mathrm{~b}$ & $7.31 \mathrm{~b}$ & $\mathrm{Y}=1.6140+0.1921 \mathrm{x}^{*}$ & 0.94 \\
\hline Maize & $1.62 \mathrm{a}$ & 2.90a & $6.28 \mathrm{a}$ & $8.01 \mathrm{a}$ & $10.05 a$ & $\mathrm{Y}=1.3780+0.2746 \mathrm{x}^{*}$ & 0.98 \\
\hline Sorghum & $1.62 \mathrm{a}$ & $2.65 a$ & $5.67 \mathrm{~b}$ & $8.51 \mathrm{a}$ & $8.95 a b$ & $\mathrm{Y}=1.3760+0.2565 \mathrm{x}^{*}$ & 0.95 \\
\hline Wheat & $1.62 \mathrm{a}$ & $3.35 a$ & $5.10 \mathrm{~b}$ & $6.75 b$ & $7.45 b$ & $\mathrm{Y}=1.8420+0.1882 \mathrm{x}^{*}$ & 0.98 \\
\hline CV (\%) & & & 16.21 & & & & \\
\hline \multicolumn{8}{|c|}{ Acetic acid (\%) } \\
\hline Millet & $5.12 \mathrm{a}$ & $4.30 \mathrm{a}$ & $2.87 \mathrm{a}$ & 2.01a & 1.33a & $\mathrm{Y}=5.1000-0.1234 \mathrm{x}^{*}$ & 0.98 \\
\hline Maize & $5.56 \mathrm{a}$ & $3.77 \mathrm{a}$ & $2.76 \mathrm{a}$ & $1.58 \mathrm{~b}$ & $1.08 \mathrm{~b}$ & $\mathrm{Y}=5.1800-0.1394 \mathrm{x}^{*}$ & 0.96 \\
\hline Sorghum & $5.45 \mathrm{a}$ & 3.84a & 2.73a & $1.49 \mathrm{~b}$ & $1.11 \mathrm{~b}$ & $\mathrm{Y}=5.1300-0.1379 \mathrm{x}^{*}$ & 0.96 \\
\hline Wheat & $5.46 \mathrm{a}$ & $4.47 \mathrm{a}$ & $3.11 \mathrm{a}$ & $2.94 a$ & $1.67 \mathrm{a}$ & $\mathrm{Y}=5.3520-0.1139 \mathrm{x}^{*}$ & 0.96 \\
\hline CV (\%) & & & 18.27 & & & & \\
\hline \multicolumn{8}{|c|}{ Propionic acid (\%) } \\
\hline Millet & 0.93a & $0.36 \mathrm{a}$ & $0.12 b$ & $0.06 \mathrm{a}$ & $0.05 a$ & $Y=0.9017-0.0722 x+0.0015 x^{2^{*}}$ & 0.98 \\
\hline Maize & $0.85 \mathrm{a}$ & $0.48 \mathrm{a}$ & $0.11 \mathrm{~b}$ & $0.08 \mathrm{a}$ & $0.04 \mathrm{a}$ & $Y=0.8589-0.0610 x+0.0011 x^{2 *}$ & 0.98 \\
\hline Sorghum & $0.88 \mathrm{a}$ & $0.40 \mathrm{a}$ & $0.13 \mathrm{~b}$ & $0.09 \mathrm{a}$ & $0.08 \mathrm{a}$ & $Y=0.8660-0.0661 x+0.0013 x^{2 *}$ & 0.99 \\
\hline Wheat & $0.94 a$ & 0.50a & $0.18 \mathrm{a}$ & $0.09 \mathrm{a}$ & $0.07 \mathrm{a}$ & $Y=0.9389-0.0651 x+0.0012 x^{2 *}$ & 0.99 \\
\hline CV (\%) & & & 23.50 & & & & \\
\hline \multicolumn{8}{|c|}{ Butyric acid (\%) } \\
\hline Millet & $0.15 a$ & $0.10 \mathrm{a}$ & $0.07 \mathrm{a}$ & $0.03 \mathrm{a}$ & $0.008 \mathrm{a}$ & $\mathrm{Y}=0.1424-0.0044 \mathrm{x}^{*}$ & 0.98 \\
\hline Maize & $0.15 a$ & $0.11 \mathrm{a}$ & $0.09 \mathrm{a}$ & $0.04 \mathrm{a}$ & $0.009 \mathrm{a}$ & $\mathrm{Y}=0.1502-0.0044 \mathrm{x}^{*}$ & 0.98 \\
\hline Sorghum & $0.14 \mathrm{a}$ & $0.11 \mathrm{a}$ & 0.09a & $0.04 \mathrm{a}$ & $0.010 \mathrm{a}$ & $\mathrm{Y}=0.1440-0.0041 \mathrm{x}^{*}$ & 0.98 \\
\hline Wheat & $0.15 \mathrm{a}$ & $0.14 \mathrm{a}$ & $0.10 \mathrm{a}$ & $0.06 \mathrm{a}$ & $0.007 \mathrm{a}$ & $\mathrm{Y}=0.1646-0.0046 \mathrm{x}^{*}$ & 0.95 \\
\hline CV (\%) & & & 22.06 & & & & \\
\hline
\end{tabular}

Means followed by different lowercases in the column (additive) are significantly different by Tukey's test $(\mathrm{P}<0.05)$. ${ }^{*}$ significant at $5 \%$ level.

[13]. When the additives were compared within each level (Table 2) with the silage without additives, no significant effects were observed between the brans $(\mathrm{P}>0.05)$. The lowest $\mathrm{pH}$ values were obtained for the maize and wheat brans when bran additional levels of $8 \%$ and $24 \%$ were used. When the brans were added at $16 \%$, only the sorghum bran differed from the wheat bran (with a higher $\mathrm{pH}$ ). At the $32 \%$ level, the millet, maize and wheat brans had similar $\mathrm{pH}$ values.

When evaluating the titratable acidity (Table 2), a linear increase was observed for all of the brans and bran levels in the silage. The 32\% addition provided increases of $9.38 \%, 12.97 \%, 10.68 \%$ and $12.73 \%$ for the millet, maize, sorghum and wheat brans, respectively, relative to the silage without any additives. [4] reported that the types of additives used could affect the $\mathrm{pH}$ and lactic acid relationships because the titratable acidity analysis reflects the general fermentative quality aspects of the silage. These relationships affect the flavor, odor, color and stability of the silage and depend on the acids that determine the $\mathrm{pH}$, especially lactic acid [14]. Relative to the silage without additives, the titratable acidity values were similar between the brans. However, at a bran level of $8 \%$, the millet and sorghum brans had lower titratable acidity values than the maize and wheat brans. At the $16 \%$ and 32\% bran levels, the millet bran differed from the wheat bran. However, the millet, maize and sorghum brans had similar values when added at $24 \%$. However, the wheat bran resulted in much higher values. The $\mathrm{N}-\mathrm{NH}_{3} / \mathrm{NT}$ concentrations decreased linearly for all brans as the additive level increased in the silage. Relative to the silage without any additives, the addition of millet, maize, sorghum and wheat bran at $32 \%$ reduced the $\mathrm{N}-\mathrm{NH}_{3} / \mathrm{NT}$ concentrations by $1.55 \%, 2.38 \%, 1.98 \%$ and $1.72 \%$, respectively (Table 2 ). This reduction resulted from the greater $\mathrm{DM}$ concentration and $\mathrm{pH}$ values when the brans were added at $32 \%$. The greater $\mathrm{DM}$ concentration and $\mathrm{pH}$ values reduced the activity of the Clostridium genus bacteria and promoted the proteolysis and the liberation of ammonia during the silage process [15]. In addition, the $\mathrm{N}-\mathrm{NH}_{3} / \mathrm{NT}$ concentration is a good 
indicator for silage quality due to its contribution to the fermentative process [10]. In addition, a reduction in the $\mathrm{N}-\mathrm{NH}_{3} / \mathrm{NT}$ concentrations was observed by [16]. These authors evaluated the fermentative characteristics of elephant grass silages with cacao bran additions and confirmed a quadratic relationship between the $\mathrm{N}-\mathrm{NH}_{3} / \mathrm{NT}^{2}$ concentrations of the silages and the bran levels. In this case, the minimum value (2.83\%) was observed in the silage with $4.5 \%$ cacao bran. The highest $\mathrm{N}-\mathrm{NH}_{3} / \mathrm{NT}$ concentrations in the silages without bran additions resulted from the lower readily fermentable carbohydrate concentrations, the lower DM concentrations and the greater buffering capacities, which are characteristic of perennial forage grasses [17]. In addition, the highest $\mathrm{pH}$ values were obtained for the silage in these treatments. By comparing the additives within each level, it was observed (Table 2) that the $\mathrm{N}-\mathrm{NH}_{3} / \mathrm{NT}$ concentrations were similar between the control without any added bran and the treatments with bran added at $8 \%, 24 \%$, and $32 \%$. However, at the $16 \%$ level, the maize bran resulted in a lower $\mathrm{N}-\mathrm{NH}_{3} / \mathrm{NT}$ concentration $(\mathrm{P}<0.05$ ) relative to the millet and wheat brans. At the $24 \%$ and $32 \%$ levels, the $\mathrm{N}-\mathrm{NH}_{3} / \mathrm{NT}$ concentrations for all of the brans were between $2.87 \%$ and $2.02 \%$. These results were greater than the results that were obtained by [18], in which elephant grass silage was evaluated. These authors identified average $\mathrm{N}-\mathrm{NH}_{3} / \mathrm{NT}$ concentrations of $3.95 \%$ following the addition of rice bran, soybean hulls, maize flour and sugar cane. Even in the treatments without additives, the $\mathrm{N}-\mathrm{NH}_{3} / \mathrm{NT}$ concentrations were considered acceptable in the silage (an average concentration of 4.36\%). Because $\mathrm{N}-\mathrm{NH}_{3}$ is a product of Clostridium fermentation and must not exceed $11 \%-12 \%$ of the total nitrogen in well-conserved silages [13], the studied silages were adequately fermented when the fermentation process did not result in the excessive breakdown of protein into ammonia. The bran additions promoted a linear relationship between the decreasing buffering capacity and the increasing millet and sorghum bran additions. In addition, the addition of maize and wheat bran resulted in a quadratic decrease in buffering capacity. The minimum buffering capacities for the linear and quadratic relationships occurred at the $28.45 \%$ and $31.81 \%$ levels, respectively, which indicated that the brans were efficient at decreasing the silage buffering capacity (Table 2). In the silages without additives and at the $16 \%$ and $24 \%$ addition levels, the buffering capacity values were similar for the additives. At the $8 \%$ level, only the addition of millet bran differed $(\mathrm{P}<0.05)$ from the wheat bran. At the 32\% level, the maize and sorghum brans resulted in lower buffering capacities $(\mathrm{P}<0.05)$ relative to the millet and wheat brans (Table 2). Similar results were obtained by [2], who evaluated the buffering capacity of silage from Tanzanian grass when maize flour was used and verified a linear reduction in buffering capacity (from 16.62 to 14.64 emg of NaOH/100 g in the DM). Regarding the soluble $\mathrm{CHO}$ concentrations, a quadratic increase occurred as the additives were added to the silage (Table 2). The addition of 32\% millet, maize, sorghum and wheat bran increased the soluble CHO concentrations by $5.55 \%, 8.50 \%, 8.25 \%$ and $6.25 \%$, respectively, relative to the silage without additives. This increase was more distinct for the maize and sorghum brans because these brans contained greater soluble CHO concentrations (Table 1). When the additives within each level were compared (Table 2), the silages without additives or with additives of $8 \%$ had similar soluble $\mathrm{CHO}$ concentrations. However, at the $16 \%$ level, only the millet bran differed $(\mathrm{P}<0.05)$ from the maize and sorghum brans (with a lower concentration). In addition, at the $24 \%$ and $32 \%$ levels, the maize and sorghum brans resulted in greater soluble $\mathrm{CHO}$ concentrations relative to the millet and wheat brans. [18] evaluated elephant grass silage with alternative products and verified that additions of rice bran, soybean hulls, maize flour and sugar cane resulted in average concentrations of $15.96 \%$. These values were greater than the values that were obtained here. When analyzing the organic acid concentrations, a linear increase in lactic acid was observed (Table 3) with increasing bran addition for the considered brans. The addition of the millet, maize, sorghum and wheat brans at 32\% resulted in increases of 5.42\%, $8.43 \%, 7.33 \%$ and $5.83 \%$, respectively, relative to the silage without any additives. This result indicated that the silage was adequately stabilized. In addition, this finding potentially resulted from the lower soluble carbohydrate concentrations in the brans, which explain the lower silage $\mathrm{pH}$ values that were observed following the higher additive levels (Table 2). Lactic acid should be the primary acid in good silage. This acid is stronger than the other acids in silage (acetic, propionic, and butyric), and therefore is usually responsible for most of the drop in silage $\mathrm{pH}$ [19]. In the silage without additives and with additives at the $8 \%$ level, the lactic acid concentrations were similar. The greatest lactic acid concentrations were obtained from the addition of maize bran at $16 \%$. At the $24 \%$ and 32\% levels, the maize and sorghum brans resulted in greater lactic acid concentrations. These results were caused by the greater soluble carbohydrate concentrations in the maize and sorghum brans. In a study that evaluated the quality of silage from a consortium of marandu grass and maize, [17] found that the lactic acid concentrations were of $6.35 \%, 7.55 \%$ and $8.37 \%$, in maize silages that were exclusive and in two intercropped cultures that were sown with marandu grass, respectively. Similar values were obtained in this study when bran levels of 
$24 \%$ and $32 \%$ were added to the silage.

The acetic acid concentrations in the silage decreased linearly in the presence of all brans as the level of addition increased with reductions of 3.79\%, 4.48\%, 4.34\% and 3.79\% for the millet, maize, sorghum, and wheat bran additions, respectively, relative to the silage without additives (Table 3). According to [11], this reduction is important because elevated acetic acid production indicates enterobacteria activity, which occurs during the initial silage fermentation stages and competes with lactic acid bacteria for nutrients. These microorganisms have little proteolytic activity. However, these microorganisms are capable of degrading some amino acids and of contributing to ammonia and biogenic amine production (such as Clostridia). According to these authors, the fermentation mechanism of enterobacteria is similar to the fermentation mechanism of heterofermentative bacteria, and results from the losses of dry materials and energy. In the silage without additives and in the silage with additives at $8 \%$ and $16 \%$, the acetic acid concentrations were similar between the studied brans. However, when the brans were added at $24 \%$ and $32 \%$, the maize and sorghum brans resulted in lower acetic acid concentrations relative to the millet and wheat brans (Table 3). A quadratic reduction occurred in the propionic acid concentration as all of the bran additions increased (Table 3). The minimum propionic acid concentrations were $24.07 \%, 27.73 \%, 25.42 \%$ and $27.13 \%$ for the millet, maize, sorghum and wheat brans, respectively. However, at a bran addition level of $16 \%$, the propionic acid concentrations were in the appropriate range (less than $0.10 \%$ ) for conserving ensiled mass [20]. The propionic acid concentrations were greater than the ideal recommended values (less than $0.10 \%$ ) in the silage without additives and in the silage with bran additions of $8 \%$. In these treatments, greater $\mathrm{pH}$ and $\mathrm{N}-\mathrm{NH}_{3} / \mathrm{NT}$ values were observed, which indicated that undesirable fermentation occurred [13] due to the greater production of weak acids. When the additives were compared within each level, the silage without additives and the silage with bran additions of $8 \%$, 24\% and 32\% did not significantly affect $(\mathrm{P}>0.05)$ the propionic acid concentrations between the studied brans (Table 3 ). In this case, only the $16 \%$ level was affected $(\mathrm{P}<0.05)$, which resulted in a greater propionic acid concentration for the wheat bran. The addition of the brans to the silage promoted a linear reduction in the butyric acid concentrations with increasing additive concentrations (Table 3). The low butyric acid concentrations following the addition of $16 \%$ bran were not effective for Clostridium fermentation. This result indicated good silage quality because molds and/or mildew were not detected in the material. The organic acid concentrations that were observed in this study for all of the brans at levels of more than $16 \%$ were sufficient for silage conservation and stability. This result indicated that the silage from the tropical grasses, which contained low soluble carbohydrate concentrations, low dry material concentrations during harvest and a high buffering capacity, requires additives to improve the conservation of the ensiled mass. Among the studied brans, the maize and sorghum bran resulted in greater organic acid concentrations relative to the millet and wheat brans. The DM concentrations increased linearly as the bran concentrations increased. These results demonstrate the importance of adding brans to absorb humidity from the ensiled mass. The studied brans were efficient for absorbing water within the silo, which improved the fermentative process and the quality of the silage. The silage without additives had the lowest DM concentrations because the ensiled material was in the in natura form and had low DM concentrations (Table 1). This finding is typical of tropical forage grasses when cut during their growth phase. Similar results were obtained by [21], who evaluated maize flour and soybean hulls in elephant grass silage, and by [3], who studied millet bran in marandu grass, xaraés grass and Piata palisadegrass silage. By comparing the additives within each level in Table 4, the silage without additives and with additive additions of $8 \%, 16 \%$ and $24 \%$ had similar DM concentrations. However, at an additive level of $32 \%$, a significant effect $(\mathrm{P}<0.05)$ was observed between the wheat and maize brans. In this case, the wheat bran achieved a DM concentration of $40.2 \%$. These results demonstrate that the addition of bran at $32 \%$ resulted in silage with recommended DM concentration that was greater than the recommended $32 \%$ [22].

The CP concentrations increased linearly as the addition levels of millet and sorghum brand increased. In addition, a quadratic increase was observed for the maize and wheat brans. The amounts of maize and wheat bran that should be added to the silage were estimated from the regression equation as $29.47 \%$ and $30.54 \%$, respectively. The CP concentrations were lower in the silage without the additives than in the Piata palisadegrass prior to ensiling (13.7\%). This result indicated that the protein content decreased during the fermentation process, which potentially resulted from the low soluble carbohydrate concentrations in the Piata palisadegrass (2.43\%) prior to ensiling. In addition, proteolytic bacteria potentially used amino acids as a source of energy for growth and metabolism. [11] explained that proteolysis is extended during fermentation when acidic conditions are not sufficient for inhibiting undesirable microorganisms. Similar results were obtained by [18], who evaluated 
Table 4. The DM, CP, EE and MM concentrations in the Piata palisadegrass silage ensiled with energetic brans.

\begin{tabular}{|c|c|c|c|c|c|c|c|}
\hline \multirow{2}{*}{ Additives } & \multicolumn{5}{|c|}{ Additive Levels (\%) } & \multirow{2}{*}{ Equation } & \multirow{2}{*}{$\mathrm{R}^{2}$} \\
\hline & 0 & 8 & 16 & 24 & 32 & & \\
\hline \multicolumn{8}{|c|}{ DM concentrations (\%) } \\
\hline Millet & $20.5 a$ & 26.3a & 29.2a & $32.1 \mathrm{a}$ & $38.7 a$ & $Y=20.9200+0.5275 x^{*}$ & 0.97 \\
\hline Maize & $18.7 \mathrm{a}$ & $26.7 \mathrm{a}$ & $28.5 \mathrm{a}$ & $31.5 \mathrm{a}$ & $34.8 \mathrm{~b}$ & $Y=20.6400+0.4625 x^{*}$ & 0.93 \\
\hline Sorghum & $20.4 \mathrm{a}$ & 28.9a & $29.5 \mathrm{a}$ & 31.4a & $38.4 \mathrm{ab}$ & $Y=22.0200+0.4813 x^{*}$ & 0.89 \\
\hline Wheat & 19.6a & $25.7 \mathrm{a}$ & 28.9a & $32.2 \mathrm{a}$ & $40.2 \mathrm{a}$ & $Y=19.7800+0.5962 x^{*}$ & 0.97 \\
\hline CV (\%) & & & \multicolumn{4}{|c|}{ CV (\%) } & \\
\hline \multicolumn{8}{|c|}{ CP concentrations (\%) } \\
\hline Millet & $8.8 \mathrm{a}$ & $11.1 \mathrm{a}$ & 13.3a & 13.1a & $14.9 \mathrm{a}$ & $Y=9.4000+0.1775 x^{*}$ & 0.91 \\
\hline Maize & 8.3a & $8.7 \mathrm{~b}$ & $9.9 \mathrm{~b}$ & $9.6 \mathrm{~b}$ & $9.9 b$ & $\mathrm{Y}=8.2171+0.1120 \mathrm{x}-0.0019 \mathrm{x}^{2 *}$ & 0.87 \\
\hline Sorghum & $8.5 a$ & $8.4 \mathrm{~b}$ & $9.5 b$ & $9.7 \mathrm{~b}$ & $10.8 \mathrm{~b}$ & $\mathrm{Y}=8.2000+0.0738 \mathrm{x}^{*}$ & 0.89 \\
\hline Wheat & $8.2 \mathrm{a}$ & $12.2 \mathrm{a}$ & $14.0 \mathrm{a}$ & $13.5 \mathrm{a}$ & 15.3a & $Y=8.5543+0.4214 x-0.0069 x^{2 *}$ & 0.95 \\
\hline CV (\%) & & & 9.52 & & & & \\
\hline \multicolumn{8}{|c|}{ EE concentrations (\%) } \\
\hline Millet & $1.6 \mathrm{a}$ & $2.4 \mathrm{~b}$ & $2.7 \mathrm{~b}$ & $3.7 \mathrm{a}$ & $3.5 b$ & $\mathrm{Y}=1.7200+0.0663 \mathrm{x}^{*}$ & 0.96 \\
\hline Maize & 1.8a & $2.3 b$ & $2.4 \mathrm{~b}$ & $3.4 \mathrm{a}$ & $3.8 b$ & $Y=1.7200+0.0638 x^{*}$ & 0.94 \\
\hline Sorghum & $1.8 \mathrm{a}$ & 2.6a & $3.4 \mathrm{a}$ & $3.7 \mathrm{a}$ & $3.7 \mathrm{~b}$ & $Y=1.6714+0.1459 x-0.0026 x^{2 *}$ & 0.99 \\
\hline Wheat & $1.8 \mathrm{a}$ & $3.2 \mathrm{a}$ & $3.1 \mathrm{a}$ & 3.9a & $4.2 \mathrm{a}$ & $\mathrm{Y}=2.1400+0.0688 \mathrm{x}^{*}$ & 0.87 \\
\hline CV (\%) & & & 6.62 & & & & \\
\hline \multicolumn{8}{|c|}{ MM concentrations (\%) } \\
\hline Millet & 2.93a & $2.17 a$ & $2.07 \mathrm{a}$ & 1.68a & $1.51 \mathrm{a}$ & $\mathrm{Y}=2.7380-0.0416 \mathrm{x}^{*}$ & 0.91 \\
\hline Maize & 3.81a & 3.42a & $3.15 \mathrm{a}$ & 2.03a & $1.65 \mathrm{a}$ & $\mathrm{Y}=3.9540-0.0714 \mathrm{x}^{*}$ & 0.94 \\
\hline Sorghum & $3.61 \mathrm{a}$ & $3.16 \mathrm{a}$ & $2.85 \mathrm{a}$ & $2.21 \mathrm{a}$ & $1.55 \mathrm{a}$ & $Y=3.6900-0.0634 x^{*}$ & 0.98 \\
\hline Wheat & 2.83a & $2.69 a$ & 2.13a & $1.89 \mathrm{a}$ & $1.76 \mathrm{a}$ & $\mathrm{Y}=2.8480-0.0367 \mathrm{x}^{*}$ & 0.94 \\
\hline CV (\%) & & & 13.01 & & & & \\
\hline
\end{tabular}

Means followed by different lowercases in the column (additive) are significantly different by Tukey’s test $(\mathrm{P}<0.05)$. ${ }^{*}$ significant at $5 \%$ level. DM = Dry matter; CP = Crude protein; EE = Ether extract; $\mathrm{MM}=$ Mineral material.

elephant grass silage and observed that low CP concentrations occurred in silage without additives due to the loss of soluble nitrogenated compounds in the effluent. However, at the $8 \%, 16 \%, 24 \%$ and $32 \%$ levels, the lowest concentrations were obtained from the maize and sorghum brans $(\mathrm{P}<0.05)$, which differed from the millet and wheat brans. The concentrations of the soluble nitrogenated compounds increased following the addition of the maize and sorghum brans. These brans contained greater CP concentrations than the other brans, which improved the silage quality (Table 1). According to [23], although the energetic content of the millet grain is less than the energetic contents of maize and sorghum, millet has a greater protein content. This greater protein content justifies the use of millet in silage. Similar results were observed by [3], who evaluated the quality of silage from three Brachiaria brizantha cultivars with different amounts of millet bran. These authors indicated that the addition of $15 \%$ millet bran to marandu, xaraés and Piata palisadegrasses resulted in CP concentrations of $14.4 \%$, $12.9 \%$ and $10.8 \%$, respectively. These concentrations were $65 \%, 92 \%$ and $52 \%$ greater, respectively, than in the silages without the millet bran. The EE concentrations of the silage increased with increasing additive concentrations, which resulted in a linear increase for the millet, maize and wheat brans. However, a quadratic increase occurred when sorghum bran was added with a maximum that occurred at a sorghum bran addition of approximately 28.06\% (Table 4). This increase was justified by the greater EE concentrations of the brans relative to the Piata palisadegrass (Table 1). These EE concentrations improved the quality of the Piata palisadegrass silage. According to the [24], diets must contain DM concentrations of less than $6 \%$ to $7 \%$ to ensure good fiber digestibility, passage rate and ruminal fermentation. In the silage without additives and at the $24 \%$ level, the EE concentrations were similar between the different brans. At the $8 \%$ and $32 \%$ levels, the millet, maize and sorghum brans had similar concentrations that differed from the wheat bran concentrations. At the $16 \%$ level, the sorghum 
and wheat bran had the highest EE concentrations. Based on the MM concentrations of the silage (Table 4), the addition of greater additive concentrations resulted in a linear reduction in MM for all of the brans. In addition, this decrease occurred as organic material was lost. The silage without any additives had the highest MM concentration. This result occurred due to the greater potential losses in these treatments with inadequate fermentation that resulted in the loss of organic material and increased the relative participation of ash (mineral material) in the DM [25]. Similar results were obtained by [26], who evaluated the inclusion of palm kernel cake in massai grass silage. These authors verified the negative linear behavior of the mineral material as a function of the palm kernel cake levels in the silage. In this case, for the inclusion of $1 \%$ cake, a mineral material reduction of $0.137 \%$ was observed. When the additives were compared within each level (Table 4), the MM concentrations were similar at all levels between the different brans but decreased with increasing levels. This fact resulted from the low MM concentrations in the brans. The NDF concentrations decreased linearly as the amount of bran in the silage increased (Table 5). This result occurred due to the greater NDF (66.5\%) concentration in

Table 5. NDF, ADF, lignin, cellulose and hemicellulose concentrations in the Piata palisadegrass silage ensiled with energetic brans.

\begin{tabular}{|c|c|c|c|c|c|c|c|}
\hline \multirow{2}{*}{ Additives } & \multicolumn{5}{|c|}{ Additive Levels (\%) } & \multirow{2}{*}{ Equation } & \multirow{2}{*}{$\mathrm{R}^{2}$} \\
\hline & 0 & 8 & 16 & 24 & 32 & & \\
\hline \multicolumn{8}{|c|}{ NDF concentrations (\%) } \\
\hline Millet & $71.55 a$ & $69.02 \mathrm{a}$ & $62.87 a$ & $61.28 \mathrm{a}$ & $54.07 \mathrm{a}$ & $\mathrm{Y}=72.2980-0.5337 \mathrm{x}^{*}$ & 0.96 \\
\hline Maize & $70.99 a$ & $66.77 a$ & 62.38a & $53.04 \mathrm{~b}$ & $52.28 \mathrm{a}$ & $\mathrm{Y}=71.3220-0.6394 \mathrm{x}^{*}$ & 0.95 \\
\hline Sorghum & $70.64 a$ & $66.39 a$ & $60.03 a$ & $57.90 \mathrm{ab}$ & $54.44 a$ & $\mathrm{Y}=70.0580-0.5111 \mathrm{x}^{*}$ & 0.97 \\
\hline Wheat & $71.38 \mathrm{a}$ & $70.34 a$ & $65.68 \mathrm{a}$ & 56.99ab & $57.37 \mathrm{a}$ & $\mathrm{Y}=72.6260-0.5171 \mathrm{x}^{*}$ & 0.90 \\
\hline CV (\%) & & & 5.15 & & & & \\
\hline \multicolumn{8}{|c|}{ ADF concentrations (\%) } \\
\hline Millet & $44.45 a$ & $41.47 a$ & $37.76 a$ & $29.34 b$ & 26.31a & $\mathrm{Y}=45.5660-0.6064 \mathrm{x}^{*}$ & 0.96 \\
\hline Maize & $45.55 a$ & $36.49 \mathrm{a}$ & $30.41 \mathrm{bc}$ & $25.12 b$ & $28.95 a$ & $Y=42.9840-0.6050 x^{*}$ & 0.92 \\
\hline Sorghum & $46.19 a$ & $38.80 \mathrm{a}$ & 27.99c & 30.56ab & $24.35 a$ & $Y=44.4760-0.6811 x^{*}$ & 0.95 \\
\hline Wheat & $46.24 a$ & $39.22 \mathrm{a}$ & $36.25 a$ & $36.06 a$ & $29.88 \mathrm{a}$ & $Y=44.7060-0.4485 x^{*}$ & 0.91 \\
\hline CV (\%) & & & 9.41 & & & & \\
\hline \multicolumn{8}{|c|}{ Lignin concentrations (\%) } \\
\hline Millet & $4.85 a$ & $4.27 \mathrm{a}$ & $3.85 a$ & $3.61 \mathrm{~b}$ & $2.95 b$ & $Y=4.7980-0.0558 x^{*}$ & 0.98 \\
\hline Maize & $4.92 \mathrm{a}$ & $4.10 \mathrm{a}$ & $3.65 \mathrm{a}$ & $3.32 \mathrm{~b}$ & $2.65 b$ & $\mathrm{Y}=4.7920-0.0665 \mathrm{x}^{*}$ & 0.97 \\
\hline Sorghum & $4.92 \mathrm{a}$ & $4.30 \mathrm{a}$ & $3.87 \mathrm{a}$ & $3.52 b$ & $2.84 \mathrm{~b}$ & $\mathrm{Y}=4.8780-0.0618 \mathrm{x}^{*}$ & 0.98 \\
\hline Wheat & $5.00 \mathrm{a}$ & $4.52 \mathrm{a}$ & $3.95 \mathrm{a}$ & $4.05 \mathrm{a}$ & $3.87 \mathrm{a}$ & $Y=5.0054-0.0795 x+0.0014 x^{2 *}$ & 0.94 \\
\hline CV (\%) & & & 5.28 & & & & \\
\hline \multicolumn{8}{|c|}{ Cellulose concentrations (\%) } \\
\hline Millet & $39.60 \mathrm{a}$ & 37.19a & 33.91a & 25.73a & 23.36a & $Y=40.7460-0.5493 x^{*}$ & 0.94 \\
\hline Maize & $40.63 a$ & 32.39a & $26.76 b$ & $26.29 a$ & $21.80 \mathrm{a}$ & $\mathrm{Y}=38.3260-0.5470 \mathrm{x}^{*}$ & 0.91 \\
\hline Sorghum & $41.26 \mathrm{a}$ & $34.50 \mathrm{a}$ & $27.04 \mathrm{~b}$ & 24.11a & 21.50a & $\mathrm{Y}=39.6640-0.6239 \mathrm{x}^{*}$ & 0.94 \\
\hline Wheat & $41.24 a$ & $34.75 a$ & $32.30 \mathrm{a}$ & 29.01a & $26.01 \mathrm{a}$ & $Y=39.9020-0.4525 x^{*}$ & 0.96 \\
\hline CV (\%) & & & 10.63 & & & & \\
\hline \multicolumn{8}{|c|}{ Hemicellulose concentrations (\%) } \\
\hline Millet & 27.10a & $27.54 a$ & 25.11a & $27.94 a$ & $27.75 a$ & ns & \\
\hline Maize & 25.43a & $26.27 \mathrm{a}$ & 27.96a & 27.91ab & 26.33a & ns & \\
\hline Sorghum & $24.45 a$ & 27.59a & $26.04 a$ & 27.33ab & 26.09a & ns & \\
\hline Wheat & $25.14 \mathrm{a}$ & $27.05 \mathrm{a}$ & $29.43 a$ & $28.93 b$ & $27.48 \mathrm{a}$ & ns & \\
\hline CV (\%) & & & 16.40 & & & & \\
\hline
\end{tabular}

Means followed by different lowercases in the column (additive) are significantly different by Tukey's test $(\mathrm{P}<0.05)$. ${ }^{*}$ significant at $5 \%$ level. NDF $=$ Neutral detergent fiber; ADF $=$ Acid detergent fiber. 
the Piata palisadegrass relative to the brans. Thus, when the silage was diluted by adding $32 \%$ millet, maize, sorghum, and wheat brans, the NDF was reduced by $32.32 \%, 35.78 \%, 29.75 \%$ and $24.42 \%$, respectively, relative to the silage without added bran. This reduction in the silage NDF concentrations was verified by [27], who added wheat bran to elephant grass silage. In addition, [3] observed a reduction in the NDF when millet bran was added to marandu, xaraés and Piata palisadegrass silage. In the silage without additives and at $8 \%, 16 \%$ and $32 \%$, the NDF concentrations were similar $(\mathrm{P}>0.05)$ between the different brans. However, at the $24 \%$ additive level, a significant effect $(\mathrm{P}<0.05)$ was observed in which the maize bran had a lower NDF concentration $(53.04 \%)$ than the millet bran. The ADF concentrations decreased linearly with increasing bran addition (Table 4). These results were derived from the low fiber concentrations that were present in the brans (Table 1). In addition, these results indicated the importance of adding brans to tropical grass silage. The addition of the brans resulted in a lower fibrous content and improved the silage quality. Within each additive level and at the $8 \%$ and 32\% additive levels, the ADF concentrations were similar. However, at the $16 \%$ additive level, the millet and wheat brans resulted in higher ADF concentrations, which differed $(\mathrm{P}<0.05)$ from the maize and sorghum brans. At the $24 \%$ additive level, only the wheat bran had a lower ADF concentration than the other brans. [28] reported that forages with ADF concentrations of approximately $40 \%$ or more resulted in low consumption and digestibility.

A linear reduction in lignin concentration occurred following the additions of the millet, maize and sorghum brans. In addition, a quadratic reduction in lignin concentrations occurred as the additive concentration of wheat bran increased in the silage. In this relationship, the minimum lignin concentration occurred at the $28.39 \%$ level. The addition of the millet, maize, sorghum and wheat brans at $32 \%$ reduced the lignin contents in the silage by $64.40 \%, 85.66 \%, 73.23 \%$, and $29.19 \%$, respectively, relative to the silage without brans. The lowest reduction was verified for the wheat bran because it contained the highest lignin (3.80\%) concentration relative to the other brans. These results are relevant for improving silage quality. In addition, the creation of food with low lignin concentrations is important because lignin is not a carbohydrate but an amorphous phenyl propanoid polymer. This polymer has a structural function, is indigestible and inhibits the digestibility of plants [29]. [13] reported that lignin has a negative influence on the degradation and effective degradability rates of cell walls in voluminous foods (in addition to having silica and cutin). When the additives were compared at each level (Table 5), it was observed that no significant effect occurred between the brans regarding lignin concentrations at the 8 and $16 \%$ levels. However, at the $24 \%$ and $32 \%$ levels, the highest lignin concentration was obtained in the wheat bran ( $\mathrm{P}<0.05$; relative to the other brans). As the bran addition levels increased, the cellulose concentrations decrease linearly. According to [13], cellulose is the most important structural component of the cell wall. However, the nutritional availability of cellulose varies from indigestible to digestible and depends on the degree of lignification. At both levels, the cellulose concentrations were between $20 \%$ and $40 \%$ DM (as recommended by [13] for tropical forages. In the silage without additives and with additives at $8 \%, 24 \%$ and $32 \%$, the cellulose concentrations were similar between the brans. However, the millet and wheat brans differed $(\mathrm{P}<0.05)$ from the maize and sorghum brans at the $16 \%$ addition level, which indicated that the millet and wheat brans had lower cellulose concentrations. In contrast, [9] verified that the addition of an additive (coffee bean hull) did not affect the cellulose concentrations in elephant grass silage, which had an average cellulose concentration of $38.5 \%$. The hemi-cellulose concentrations were not affected by the additives or their concentrations and remained between $24.45 \%$ and $29.43 \%$. These hemi-cellulose concentrations were compatible with those recommended by [11] for grasses (between $10 \%$ and $30 \%$ of DM). The TDN concentrations increased linearly as the bran addition increased in the silage for all of the brans (Table 6). This result was likely caused by the two following factors: the greater TDN concentrations that were contained in the brans relative to the Piata palisadegrass (Table 1) and the chemical-bromatological characteristics of these additives. Elevated chemical-bromatological characteristics were directly linked with the presence of energy sources, such as crude protein, ether extract and non-fiber carbohydrates, and with reduced fractions, which were inversely related to energy sources, such as NDF, ADF and lignin [27]. When the brans were compared within each level (Table 6), the treatments without additives and with additives at $8 \%$ level had similar TDN concentrations. When the brans were added at $16 \%, 24 \%$ and $32 \%$, only the wheat bran had a significantly higher TDN concentration $(\mathrm{P}<0.05)$ relative to the other brans. This result occurred because the millet, maize and sorghum brans contained higher TDN concentrations relative to the wheat bran (Table 1). [25] observed that adding 33.7\% wheat bran to tanzania grass silage increased the TDN concentrations from $53.52 \%$ to $63.70 \%$. This result is less than the average TDN concentration (67.06\%) that was recorded here when $32 \%$ wheat bran was added. 
Table 6. The concentrations of total digestible nutrients (TDN) and the in vitro digestibility of dry matter (IVDMD) of the Piata palisadegrass silage that was ensiled with energetic brans.

\begin{tabular}{|c|c|c|c|c|c|c|c|}
\hline \multirow{2}{*}{ Additives } & \multicolumn{5}{|c|}{ Additive Levels (\%) } & \multirow{2}{*}{ Equation } & \multirow{2}{*}{$\mathrm{R}^{2}$} \\
\hline & 0 & 8 & 16 & 24 & 32 & & \\
\hline \multicolumn{8}{|c|}{ TDN concentrations (\%) } \\
\hline Millet & $60.07 a$ & $61.75 a$ & $66.78 \mathrm{a}$ & $67.32^{\mathrm{a}}$ & 70.03a & $Y=60.0920+0.3186 x^{*}$ & 0.94 \\
\hline Maize & $59.54 a$ & 63.89a & $66.81 \mathrm{a}$ & $70.10^{\mathrm{a}}$ & $71.01 \mathrm{a}$ & $Y=60.4400+0.3644 x^{*}$ & 0.96 \\
\hline Sorghum & $59.24 a$ & $62.78 \mathrm{a}$ & $67.97 a$ & $68.98^{\mathrm{a}}$ & $70.21 \mathrm{a}$ & $Y=60.2080+0.3518 x^{*}$ & 0.91 \\
\hline Wheat & $59.21 \mathrm{a}$ & $62.55 a$ & $64.00 \mathrm{~b}$ & $65.30 \mathrm{~b}$ & $67.06 \mathrm{~b}$ & $Y=59.9340+0.2306 x^{*}$ & 0.96 \\
\hline CV (\%) & & & 2.41 & & & & \\
\hline \multicolumn{8}{|c|}{ IVDMD concentrations (\%) } \\
\hline Millet & $56.70 a$ & $66.55 a b$ & $68.94 a$ & $71.02^{\mathrm{a}}$ & 78.59a & $\mathrm{Y}=58.7100+0.6031 \mathrm{x}^{*}$ & 0.92 \\
\hline Maize & $55.95 a$ & $68.43 a$ & $70.93 a$ & $71.49^{\mathrm{a}}$ & $76.01 \mathrm{a}$ & $Y=57.3746+1.1776 x-0.0199 x^{2 *}$ & 0.91 \\
\hline Sorghum & $56.70 \mathrm{a}$ & $62.60 \mathrm{~b}$ & $68.86 a$ & $71.99^{\mathrm{a}}$ & 76.69a & $Y=57.4940+0.6171 x^{*}$ & 0.98 \\
\hline Wheat & $56.70 \mathrm{a}$ & $64.20 \mathrm{ab}$ & 70.80a & $69.23^{\mathrm{a}}$ & $72.24 \mathrm{~b}$ & $Y=56.9620+1.0639 x-0.0191 x^{2 *}$ & 0.94 \\
\hline CV (\%) & & & 3.52 & & & & \\
\hline
\end{tabular}

Means followed by different lowercases in the column (additive) are significantly different by Tukey's test (P < 0.05). ${ }^{*}$ significant at $5 \%$ level. TDN = Total digestible nutrient; IVDMD = In vitro digestibility of dry matter.

The Increasing the millet and sorghum bran additives resulted in a linear increase in IVTD (Table 6) (38.6\% and $35.2 \%$, respectively) when the silage without additives was compared with the silage with 32\% additives. However, for the maize and wheat brans, a quadratic increase occurred as the additive levels were increased. In this case, the maximum IVTD was estimated at the $29.59 \%$ level for the maize bran and at the $27.85 \%$ level for the wheat bran. These results are most likely correlated with the low fibrous fraction concentrations in the brans (Table 1), which result in greater silage digestibility. According to [30], the increase in digestibility is most likely associated with modifications in the chemical composition of the fraction that result in lower NDF, ADF and hemicellulose concentrations, which make digestible carbohydrates available to microorganisms in the rumen. [13] indicated that the IVTD increases with the addition of concentrates due to the elevation of non-structural carbohydrates, which are more digestible relative to structural carbohydrates. In the silage without additives and with additives at $16 \%$ and $24 \%$, the IVTD concentrations were similar between the brans. At the $8 \%$ level, a significant difference $(\mathrm{P}<0.05)$ occurred between the maize and sorghum brans. In addition, at the $32 \%$ level, the wheat bran had a lower IVTD concentration relative to the other brans. This result was correlated with the higher lignin concentrations in the wheat bran. By estimating the additional average costs of the different additives and levels, it was observed (Table 7) that increasing the additive concentrations increased the final production cost. The wheat bran resulted in the greatest increase in production cost per ton of Piata palisadegrass silage. In contrast, the sorghum bran resulted in the smallest increase in production cost. However, the millet bran is an important option for silage addition because its average additional cost is only slightly higher than the annual additional cost of sorghum.

However, the increasing costs did not increase in proportion with the variations after bran addition. Thus, the marginal cost indicated that the cost of the brans increased as their addition concentration increased (Table 8). However, from one level to another, only small variations occurred. These results demonstrate the advantages of adding higher bran concentrations (24\% and 32\%) because the bran benefits the silage quality and only slightly increases the final average cost of the silage. However, lower variations were obtained for the sorghum and millet brans, which indicated a better economic return.

\section{Conclusion}

Energetic brans are a good source of additives for Piata palisadegrass silage because they improve the qualitative and nutritional fermentative characteristics of the silage. The maize and wheat brans were more efficient for improving silage fermentation, and the millet bran was the most efficient for improving the silage bromatological characteristics. However, the wheat bran had the greatest effect on the final production cost, and the sorghum 
Table 7. Average costs of the additives in the production of the Piata palisadegrass silage.

\begin{tabular}{ccccccc}
\hline & & \multicolumn{5}{c}{ Additive Levels (\%) } \\
\cline { 3 - 7 } Additives & Costs $^{*} \mathrm{R} \$ \mathrm{~kg}^{-1}$ & 0 & 8 & 16 & 24 & 32 \\
\cline { 3 - 7 } & & & \multicolumn{5}{c}{$\mathrm{R} \$ \cdot \operatorname{ton}^{-1}$} \\
Millet & 0.24 & - & 17.90 & 33.33 & 46.77 & 58.59 \\
Maize & 0.36 & - & 26.54 & 49.43 & 69.35 & 86.87 \\
Sorghum & 0.23 & - & 17.16 & 31.95 & 44.84 & 56.16 \\
Wheat & 0.50 & - & 37.04 & 68.97 & 96.77 & 121.21 \\
\hline
\end{tabular}

"Prices quoted in the market of Rio Verde-GO, Brazil.

Table 8. The marginal costs of adding energetic brans to the Piata palisadegrass silage at different levels.

\begin{tabular}{cccccc}
\hline & \multicolumn{5}{c}{ Additive Levels (\%) } \\
\cline { 2 - 6 } Additives & 0 & 8 & 16 & 24 & 32 \\
\cline { 2 - 6 } & - & \multicolumn{5}{c}{ R\$.ton ${ }^{-1}$} \\
Millet & - & 17.90 & 15.43 & 13.44 & 11.82 \\
Maize & - & 26.54 & 22.89 & 19.92 & 17.52 \\
Sorghum & - & 17.16 & 14.79 & 12.89 & 11.32 \\
Wheat & - & 37.04 & 31.93 & 27.80 & 24.40 \\
\hline
\end{tabular}

and millet brans were the most economically viable. Overall, the addition of $24 \%$ bran is recommended. This addition level will improve silage quality with limited variations in the average silage production cost.

\section{References}

[1] Santos, E.M. and Zanine, A.M. (2006) Silagem De Gramíneas Tropicais. Colloquium Agrariae, 2, 32-45. http://dx.doi.org/10.5747/ca.2006.v02.n1.a21

[2] Avila, C.L. da S., Pinto, J.C., Tavares, V.B. and Dos Santos, Í.P.A. (2006) Avaliação dos Conteúdos de Carboidratos Solúveis do Capim-Tanzânia Ensilado com Aditivos. Revista Brasileira de Zootecnia, 35, 648-654.

[3] Costa, K.A.P., Assis, R.L., Guimarães, K.C., Severiano, E.C., Assis Neto, J.M., Crunivel, W.S., Garcia, J.F. and Santos, N.F. (2011) Silage Quality of Brachiaria brizantha Cultivars Ensiled with Different Levels of Millet Meal. Arquivo Brasileiro de Medicina Veterinária e Zootecnia, 63, 188-195. http://dx.doi.org/10.1590/S0102-09352011000100028

[4] Silva, D.J. and Queiroz, A.C. (2002) Análise de Alimentos (Métodos Químicos e Biológicos). 3rd Edition, Imprensa Universitária da UFV, Viçosa, 235p.

[5] Bonassi, I.A. (1977) Determinação de Ácidos Orgânicos em Silagens por Meio de Cromatografia Gasosa. (Adaptação do método de Wilson. 1971). Universidade Estadual Paulista, Jaboticabal, 40p. Dissertação (Mestrado em Zootecnia) —Universidade Estadual Paulista.

[6] Chandler, P. (1990) Energy Prediction of Feeds by Forage Testing Explorer. Feedstuffs, 62, 12.

[7] Tilley, J.M.A. and Terry, R.A. (1963) A Two Stage Technique for in Vitro Digestion of Forages Crops. Journal of the British Grassland Society, 18, 104-111. http://dx.doi.org/10.1111/j.1365-2494.1963.tb00335.x

[8] Ferreira, D.F. (2000) Análises Estatísticas por Meio do Sisvar Para Windows Versão 4.0. In: Reunião Anual Da Região Brasileira Da Sociedade Internacional De Biometria, UFSCar, São Carlos, 255-258.

[9] Bernardino, F.S., Garcia, R., Rocha, F.C., Souza, A.L. and Pereira, O.G. (2005) Produção e Características do Efluente e Composição Bromatológica da Silagem de Capim-Elefante Contendo Diferentes Níveis de Casca de Café. Revista Brasileira de Zootecnia, 34, 2185-2191. http://dx.doi.org/10.1590/S1516-35982005000700004

[10] Babayemi, O.J. (2009) Silage Quality, Dry Matter Intake and Digestibility by West African Dwarf Sheep of Guinea Grass (Panicum maximum cv Ntchisi) Harvested at 4 and 12 Week Regrowths. African Journal of Biotechnology, 8, 3983-3988. http://dx.doi.org/10.5897/AJB09.570

[11] Mcdonald, P., Henderson, A.R. and Heron, S.J.E. (1991) The Biochemistry of Silage. 2nd Edition, Chalcombe Pub., Marlow, 340p.

[12] Tomich, T.R., Rodrigues, J.A.S., Tomich, R.G.P., Gonçalves, L.C. and Borges, I. (2004) Potencial Forrageiro de 
Híbridos de Sorgo com Capim-Sudão. Arquivos Brasileiros de Medicina Veterinária e Zootecnia, 56, 258-263. http://dx.doi.org/10.1590/S0102-09352004000200017

[13] Van Soest, P.J. (1994) Nutritional Ecology of the Ruminant. 2nd Edition, Cornell, Ithaca, 476p.

[14] Nussio, L.G., Simas, J.E.C. and Lima, M.L.M. (2001) Determinação do Ponto de Maturidade Ideal Para Colheita do Milho Para Silagem. In: Nussio, L.G., Zopollato, M. and Moura, J.C (Eds.). Milho para a silagem. FEALQ, Piracicaba, 11-26.

[15] Teixeira, F.A., Veloso, C.M., Pires, A.J., Silva, F.F. and Nascimento, P.V.N. (2008) Perdas na Ensilagem de CapimElefante Aditivado Com Farelo de Cacau e Cana-de-Açúcar. Arquivo Brasileiro de Medicina Veterinária e Zootecnia, 60, 227-233. http://dx.doi.org/10.1590/S0102-09352008000100031

[16] Carvalho, G.G.P., Garcia, R., Pires, A.J.V., Pereira, O.G., Fernandes, F.E.P. and Carvalho, B.M.A. (2008) Características Fermentativas de Silagens de Capim-Elefante Emurchecido ou Com Adição de Farelo de Cacau. Arquivo Brasileiro de Medicina Veterinária e Zootecnia, 60, 234-242.. http://dx.doi.org/10.1590/S0102-09352008000100032

[17] Leonel, F.P.L., Pereira, J.C. and Costa, M.G. (2009) Consórcio Capim-Braquiária e Milho: Comportamento Produtivo das Culturas e Características Nutricionais e Qualitativas das Silagens. Revista Brasileira de Zootecnia, 38, 166-176. . http://dx.doi.org/10.1590/S1516-35982009000100021

[18] Monteiro, I.J.G., De Abreu, J.G., Cabral, L. da S., Ribeiro, M.D. and Dos Reis, R.H.P. (2011) Silagem de CapimElefante Aditivada Com Produtos Alternativos. Acta Scientiarum. Animal Sciences, 33, 347-352. http://dx.doi.org/10.4025/actascianimsci.v33i4.12629

[19] Kung, L. and Shaver, R. (2002) Interpretation and Use of Silage Fermentation Analyses Reports. Focus on Forage, 3 , $1-5$.

[20] Kung Jr., L. (2001) Aditivos Microbianos e Químicos Para Silagem: Efeitos na Fermentação e Resposta Animal. In: Workshop Sobre Milho Para Silagem. 2.. 2001. Piracicaba. Anais..., Fundação de Estudos Agrários Luiz de Queiroz.. Piracicaba, 53-74.

[21] Andrade, I.V.O., Pires, A.J.V., Carvalho, G.G.P., Veloso, C.M. and Bonomo, P. (2010) Fracionamento de Proteína e Carboidratos em Silagens de Capim-Elefante Contendo Subprodutos Agrícolas. Revista Brasileira de Zootecnia, 39, 2342-2348. http://dx.doi.org/10.1590/S1516-35982010001100005

[22] Muck, R.E. and Shinners, K.J. (2001) Conserved Forage (Silage and Hay): Progress and Priorities. In: International Grassland Congress, 19. FEALQ, Piracicaba.

[23] Guimaraes Jr., R., Gonçalves, L.C., Maurício, R.M., Pereira, L.G.R., Tomich, T.R., Pires, D.A.A., Jayme, D.G. and Sousa, L.F. (2008) Cinética de Fermentação Ruminal de Silagens de Milheto. Arquivo Brasileiro de Medicina Veterinária de Zootecnia, 60, 1174-1180. http://dx.doi.org/10.1590/S0102-09352008000500020

[24] National Research Council—NRC (2001) Nutrient Requirements of Dairy Cattle. 7th Edition, NRC, Washington DC, 381p.

[25] Ashbell, G. (1995) Basic Principles of Preservation of Forage. By-Products and Residues as Silage or Hay. Agricultural Research Organization. The Volcani Center, Bet Dagan, 58p.

[26] Oliveira, R.L., Ribeiro, O.L., Bagaldo, A.R., Lima, L.S., Borja, M.S., Correia, B.R., Costa, J.B. and Leão, A.G. (2011) Torta de Dendê Oriunda da Produção do Biodiesel na Ensilagem de Capim-Massai. Revista Brasileira de Saúde e Produção Aninal, 12, 881-892.

[27] Ribeiro, X.R.R., Oliveira, R.L., Bagaldo, A.R., Faria, E.F.S., Garcez Neto, A.F., Silva, T.M., Borja, M.S. and Cardoso Neto, B.M. (2008) Capim-Tanzânia Ensilado Com Níveis de Farelo de Trigo. Revista Brasileira de Saúde e Produção Animal, 9, 631-640.

[28] Nussio, L.G., Manzano, R.P. and Pedreira, C.G.S. (1998) Valor Alimentício em Plantas do Gênero Cynodon. In: Simpósio Sobre Manejo da Pastagem, 15, FEALQ/ESALQ, Piracicaba, 203-242.

[29] Maranhão, C.M.A., Silva, C.C.F., Bonomo, P. and Pires, A.J.V. (2009) Produção e Composição Químico Bromatológica de Duas Cultivares de Braquiária Adubadas Com Nitrogênio e Sua Relação com o Índice SPAD. Acta Scientiarum. Animal Sciences, 31, 117-122. http://dx.doi.org/10.4025/actascianimsci.v31i2.4305

[30] Fernandes, L.O., Reis, R.A., De Rodrigues, L.R.A., Ludic, I.L. and Manzan, R.J. (2002) Qualidade do Feno de Braquiária Decumbens Stapf. Submetido ao Tratamento Com Amônia Anidra ou Uréia. Revista Brasileira de Zootecnia, 31, 1325-1332. http://dx.doi.org/10.1590/S1516-35982002000600002 